\title{
Article
}

\section{Feminism and new horizons: A gendered-view of sustainability. A theoretical model of (un)compliance}

\author{
J. Agustín Franco Martínez 1,**, Manuel Pulido Fernández ${ }^{2}$ \\ 1 Department of Economics, University of Extremadura, Cáceres, Spain; franco@unex.es \\ 2 Department of Geography, University of Extremadura, Cáceres, Spain; mapulidof@unex.es \\ * Correspondence: franco@unex.es; Tel.: +34-927-257-480
}

\begin{abstract}
This article explores the synergies and progression of feminism towards a comprehensive, emancipatory and sustainable policy from a theoretical point of view, particularly from a radical gender focus, suggesting the masculinist theory as a complement in the fight against the patriarchal-capitalist system, whose greatest achievement was to use a 'feminist rhetoric' with no feminist content, which implies a hidden reconfiguration, even more patriarchal, of the geographical borders of countries from the notion of State-nations to the entrepreneurial-nations. A theoretical model is proposed to analyse the adoption and compliance feminist behaviour in order to identify the uncompliant and unsustainable behaviour, that is, the friendly machismo or feminism light. Finally, in a preliminary manner, the foundations of a new masculinist theory and policy will be listed as a necessary step towards a deeply feminist and radical emancipatory policy.
\end{abstract}

Keywords: Patriarchy; capitalism; feminism; behaviour; masculinism.

\section{Introduction}

The situation of feminist thinking today is in a state of effervescence, although much of that debate is only frothed and offensive, unfortunately, not only at the level of public opinion, but even at the academic level [1,2]. However, feminism and its debates are not at all exhausted, for example, on the unification of feminist thought or sextremism or new masculinities or emergent masculinism.

According to Millett, it must be emphasized that feminism will be lame if it forgets that the two central principles of patriarchy are, on the one hand, the subjection of women to men; and on the other hand, the subjection of young men to older men [3]. Patriarchy operates by gender and by generation. As long as there is machismo and patriarchalism there will be no a beyond for feminism or for any emancipatory current. Just as there is no question about humanity beyond oxygen. There is, therefore, to be warned of logical, ideological and ethical pitfalls.

Before precipitously decrying the demise of feminism, we must not forget the Femen sextremism of 2008 [4] and, of course, the always unjustly forgotten feminist men, thinkers, activists, and organizations of the new masculinities.

In general we all recognize the strong patriarchy or rude machismo [5] (p. 1): "Particularly, we suspected that gender studies are crippled academically by an overriding almost-religious belief that maleness is the root of all evil". But it is more difficult to detect the friendly machismo or the art of misogyny or Feminism Lite or light [6]. Here the battle is fought today. Thus, friendly machismo becomes feminist under the name of 'liberal feminism', in fact, feminism zombie.

We were already warned by Chimamanda Ngozi about 'light feminism', which is not such feminism [6]: "Beware the danger of what I call Feminism Lite. It is the idea of conditional female equality. Reject this entirely. It is a hollow, appeasing, and bankrupt idea. Being a feminist is like being pregnant. You either are or you are not. You either believe in the full equality of women, or you do not". Moreover, Ngozi adds [6]: "If a woman has power then why do we need to disguise that she has power? But here is a sad truth, our world is full of men and women who do not like powerful women. We have been so conditioned to think of power as male, that a powerful woman is 
an aberration. And so she is policed. (...) We judge powerful women more harshly than we judge powerful men. And Feminism Lite enables this".

As Kate Millett said in Sexual Politics, if we want to be free we must first break with religion, that strong chain that is our blind acceptance of traditional ideas, the retrograde conception of sex, the phallic myth and the condemnation of the female body and sexuality [3].

Nazanín Armanian points out that there is no 'religious feminism' because no religion claims the equality of rights, not only between women and men, not even among men of different religions. 'Religious feminism' emerges to 'interpret' religions well, in a modern and egalitarian rhetoric way. But this is incompatible, absolutely false, impossible [7].

The Femen Manifesto also expresses it clearly. Religion is a pillar of patriarchal oppression, along with dictatorships and the sex industry [4]: "Where religion begins, feminism ends". "Religion is the armed wing of the patriarchal dictatorship, and it only causes intolerance, war and exclusion from the moment it is granted a place in the public space". In religious organizations "women are perpetually relegated to subaltern positions. Therefore, the atheist woman represents, by definition, the lowest rung of the ladder".

Table 1. Review of similarities between feminism and other critical thoughts

\begin{tabular}{|c|c|c|}
\hline $\begin{array}{c}\text { Synergies of } \\
\text { feminism and... }\end{array}$ & Similarities (common fights) & $\begin{array}{c}\text { Some } \\
\text { authors }\end{array}$ \\
\hline Marxism & $\begin{array}{l}\text {-Marxism and feminism queer link: deconstruction of gender and } \\
\text { abolition of class society. } \\
\text {-Fight against economic and cultural injustice. } \\
\text {-Women are exploited by capitalism through care work. } \\
\text {-The accumulation of capital is well suited to the patriarchal social } \\
\text { structure and perpetuates it. } \\
\text {-The patriarchal mode of production determines the relations of } \\
\text { oppression between man and woman. } \\
\text {-The conditions of life are degraded and the social inequalities multiply. }\end{array}$ & [9-12] \\
\hline $\begin{array}{c}\text { Institutionalism/ } \\
\text { Post-keynesianism }\end{array}$ & $\begin{array}{l}\text {-Economy beyond mercantile production. } \\
\text {-Relevance of non-waged work. } \\
\text {-Critical view of the homo economicus model. } \\
\text {-Cultural origin of knowledge and social perceptions. } \\
\text {-Social rules and gender biases influence in behaviour. } \\
\text {-Relevance of relations of power in the evolution of socio-economic } \\
\text { structures. }\end{array}$ & [13-16] \\
\hline $\begin{array}{l}\text { Development } \\
\text { Studies }\end{array}$ & $\begin{array}{l}\text {-Pos-developmentarism and decolonial thought and ecofeminism. } \\
\text {-Critical view of development, of neoliberal model related to crisis } \\
\text { management, and of global inequalities (wage gap, global care chains, } \\
\text { neo-extractivism). }\end{array}$ & {$[17-20]$} \\
\hline Ecological thought & $\begin{array}{l}\text {-Visibilization of human development. } \\
\text {-Preference for the balance between life and nature. } \\
\text {-Importance of interdependence and ecodependence. }\end{array}$ & [21-23] \\
\hline $\begin{array}{l}\text { Other common } \\
\text { ideas }\end{array}$ & $\begin{array}{l}\text {-Critical view of the limits of the conventional economy. } \\
\text {-Demonstrate the importance of gender relations. } \\
\text {-Commitment of theory with the transformation of situations of } \\
\text { inequality. }\end{array}$ & [24-28] \\
\hline
\end{tabular}

Source: Our own from [29].

Finally, as Teresa Mollá stresses [8]: "The feminist movement has among its virtues the capacity for evolution and adaptation to each historical moment. Precisely because it must be alert to the new forms that patriarchy uses to provoke and try to impose its laws". The maturity of feminist thought must therefore be vindicated, not only for the electoral vote, but also to lead. Leading the destiny of humanity. For this reason, feminism continually seeks dialogue and synergies related to other 
sources of critical thought, such as Marxism, institutionalism, development studies, ecological line, etc. (Table 1).

\section{Materials and Methods}

This paper suggests a gender methodology based on an extended cost-benefit model applied to the patriarchy as a paradigmatic corruption model -its pillars are opportunity, incentive and legitimacy or OIL model- [30,31]. Particularly, these three pillars are observed in all the continuum of possible behaviours, from corruption to transparency, from patriarchy to non-patriarchy.

This methodology studies the effectiveness of an active gender policy related to two key behaviours, adoption and compliance of feminist practices and values, that is, an active feminist, non-patriarchal behaviour.

This gender model assumes neutrality towards risk, although the risk averse behaviour of some noncompliant players changes the findings quantitatively, the qualitative nature of them remains unaltered. It is assumed that while adoption of non-patriarchal practices is highly benefit for all society (it increases the net returns to equality of all players), it increases the net returns to equality of the less convinced players by relatively less.

\section{Results}

\subsection{Theoretical implications of the OIL model}

Theoretical results on (corrupt) non-compliant behaviour (Bfnp) with the objectives of a strategic gender policy indicate several relevant points regarding a new masculinistic thought:

1) Opportunity level: A Feminism Lite policy creates (economic, social and/or moral) incentives for all noncompliant players to masquerade as adopters and to claim social benefits and recognitions for which they have not fighted.

2) Incentive level: The noncompliant behaviour increases with the adoption costs of feminist practices and values, and falls with an increase in the level of social recognition and the number of feminist privileges and other social rewards.

3) Legitimacy level: Social and feminist recognitions have a double effect (direct/indirect) on noncompliant behaviour (false-adopters): For example, an increase in public recognitions increases/reduces the noncompliant incentives by increasing the expected benefits/opportunity cost associated with the false-adopter behaviour. The magnitude of these effects is determined by the probability to be audited and penalized. Particularly, the equilibrium audit frequency depends on the costs of monitoring players and the available budget to gender policy.

\subsection{Equations of the OIL model}

The main equations of the OIL model are the next:

$$
\begin{gathered}
\mathrm{B}=\mathrm{f}(\mathrm{O}, \mathrm{I}, \mathrm{L})=\mathrm{A}_{1} \text { Oportunity }+\mathrm{A}_{2} \text { Incentive }+\mathrm{A}_{3} \text { Legitimacy } \\
\mathrm{Bp}=\mathrm{Bp}_{0}+\mathrm{a}_{1} \mathrm{C}+\left(\mathrm{L}_{0}+\mathrm{a}_{1} \mathrm{R}\right)=\mathrm{a}_{1}(\mathrm{C}+\mathrm{R})+\mathrm{Bp}_{0}+\mathrm{L}_{0} \\
\mathrm{Bnp}=\left(1-\mathrm{a}_{3}\right) \mathrm{Bnp}_{0}+\mathrm{a}_{2} \mathrm{C}=\mathrm{a}_{2} \mathrm{C}+\mathrm{Bnp}_{0}+\left(-\mathrm{a}_{3}\right) \mathrm{Bnp}_{0} \\
\mathrm{Bfnp}=\mathrm{Bp}_{0}+\mathrm{a}_{1} \mathrm{C}+\left(1-\mathrm{a}_{4}\right)\left(\mathrm{L}_{0}+\mathrm{a}_{1} \mathrm{R}\right)=\mathrm{a}_{1}\left(\mathrm{C}+\mathrm{R}-\mathrm{a}_{4} \mathrm{R}\right)+\mathrm{Bp}_{0}+\left(1-\mathrm{a}_{4}\right) \mathrm{L}_{0}
\end{gathered}
$$

Where:

(1): The general equation of benefit is a function of three macrofactors: Oportunity, Legitimacy and Incentive. Where $\mathrm{Ai}$ are the parameters.

(2): Benefits of patriarchal behaviour (Bp) depends on a basic benefit ( $\left.\mathrm{Bp}_{0}\right)$, both Compromise and Rewards factors ( $C$ and $R$ ) are extra premium weighted by parameter a1 or opportunity parameter, and a Legitimacy factor $\left(\mathrm{L}_{0}\right)$.

(3): Benefits of non-patriarchal behaviour (Bnp) depends on a basic benefit (Bnpo), a compromise factor $(\mathrm{C})$ weighted by parameter a2 and a legitimacy element that it is a proportional penalty (a3) of the basic benefit. 
(4): Benefits of false non-patriarchal behaviour (Bfnp) equals (2) model and adds a proportional penalty (a4) to ponderate legitimacy and rewards factors.

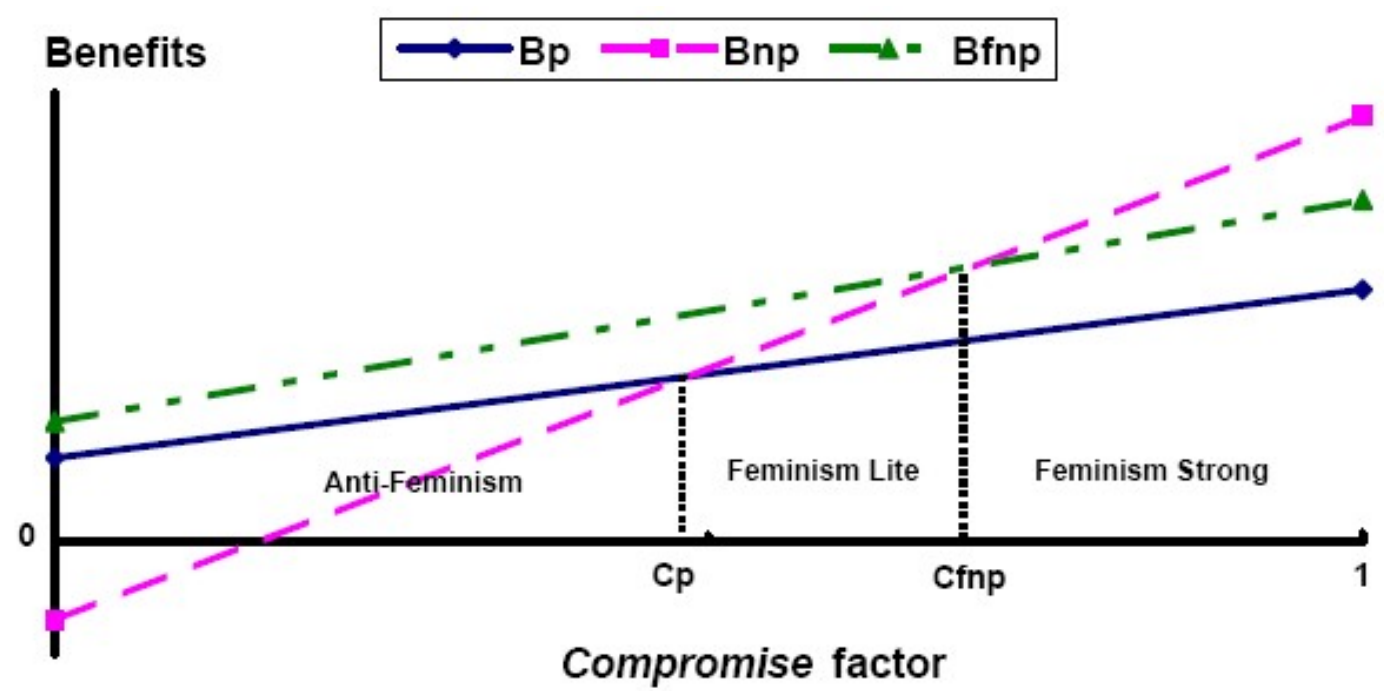

Figure 1. OIL Model. Situation with high social support of patriarchy.

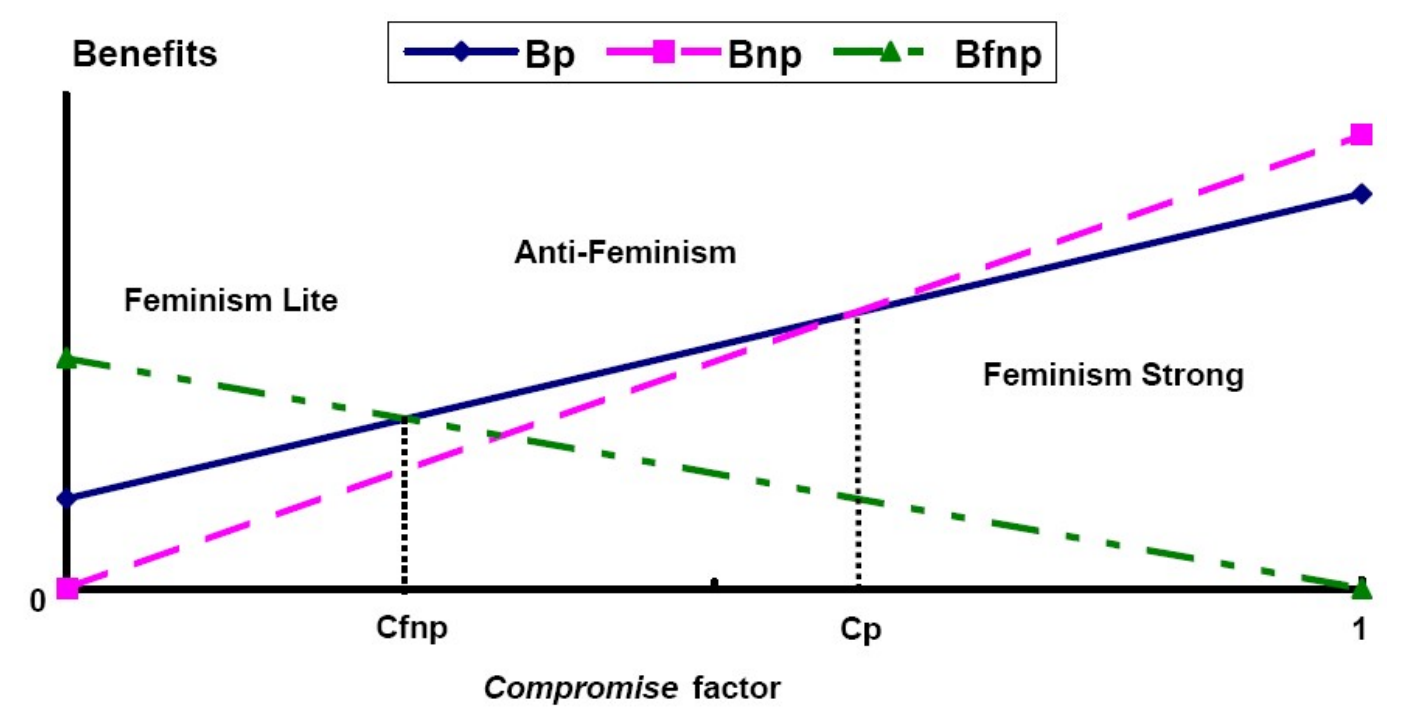

Figure 2. OIL Model. Situation with low social support of patriarchy.

\subsection{Figures}

A graphical analysis is summarized in Figures 1 and 2. In the first situation (patriarchal behaviour with high social support, $\mathrm{L}_{0}>0$ and $\mathrm{a}_{3}>\mathrm{a}_{4}$ ) we see the different points of player demarcation, including a weak gender policy.

In the second situation (patriarchal behaviour with low social support, $\mathrm{L}_{0}=0$ and $\mathrm{a}_{3}<\mathrm{a}_{4}$ ), we see some relevant changes.

\section{Discussion}

"Our stories, Wade's and mine, describe the lives of boys and men for thousands of years, boys who were beaten by their fathers, whose capacity for love and trust was crippled almost at birth and 
whose best hope, if any, for connection with other human beings lay in an elegiac detachment, as if life were over. It's how we keep from destroying in turn our own children and terrorizing the women who have the misfortune to love us; how we absent ourselves from the tradition of male violence; how we decline the seduction of revenge". (Rolfe Whitehouse. Character in the film Affliction -based on a novel by Russell Banks-, played by Willem Dafoe and directed by Paul Schrader in 1997).

\subsection{Opportunity level: Gender-generation system}

To complement the strategic rehabilitation of male-chauvinism it is necessary to develop the focus of masculinists as part of the double helix of emancipatory thought. Masculinism must be understood as the current of thought that becomes aware of masculinity and the abuse of power of patriarchy, which seeks to repair the damage caused, assuming an emancipatory vanguard position in the defence of victims of patriarchy. Masculinism also stems from the conviction of male violence against men, especially in their childhood, when they are children.

Masculinism provides some indispensable evidence: The difference between men and women engendered by the oppression of young men from older men. Masculinism and feminism complement each other like the two sides of a coin. Their conflicting counterparts are hembrism and male-chauvinism. Chauvinistic hegemony makes the study of hembristic maculinism (or kind hembrism) trends less interesting when faced with the more consolidated male-chauvinistic feminism (or friendly machismo or feminism lite or light).

Masculinism reflects primarily upon the pain caused by patriarchal violence and it elaborates a complementary perspective on the maternal symbolic order. The very existence of the male would be impossible without the mother. However, the Christian story of Creation places the woman in a secondary place. She comes from the rib of the man. This is a cancerous belief. It is the beginning of the atrocious madness of male chauvinism. The expression of an existential ontological fear: the existence of the male would be impossible without women. The expression of a brutal mistrust, an absolute lack of confidence in the only reality in which there is no room for reasonable doubt. The fear of the creature (male) of being aborted causes the abortion of its own progenitor, of its own mother. The vanity of the imaginary man has begun. Trust has been transmuted into faith.

From this perspective, it is clear that male-chauvinism is a faith of which it is better to be an atheist. In order to give birth to God the Father, it was necessary to abort the last mother, even the smallest and insignificant of the mothers: the atheist mother. The 'atheist mother' is perhaps best known as an example of those women who the Holy Catholic Inquisition burned at the stake as witches. God is represented as the authentic basis of the construction of huge pyramids of misogyny and homophobia.

All feminism contains masculinism in its DNA. All masculinism contains feminism in its DNA. Both currents constitute an indispensable part of the tradition of emancipation. Without such complicity, the progression of humanity, when faced with the ongoing temptations of involution and massive self-destruction, would not be understood.

The progress of humanity can be described as a spiral arising from the antagonism between belief and science. This spiral of progress can help to understand the historical struggles for the liberation of all dominion, especially of religious dominions (from moralistic to economistic order). A first cycle of the childlike relationship between belief and science is the theological system (like incubation of proto-patriarchy) that prioritizes always belief about science. Until reaching a cycle in which society leaves behind childhood, a process of emancipation that it subordinates forever the realm of belief to the reason, culminating in the abolition of patriarchy and the end of the political prehistory of humanity.

\subsection{Incentive level: The virginisation process of young men}

In order to develop and recognise the genuine contribution of masculinism to the dignifying debate of the human being it is necessary to distinguish between objective and subjective masculinist 
theories of pain, on the price paid by society for the free circulation of patriarchal values and ideas. The objective theory of male-chauvinistic pain understands the price of patriarchy as being equivalent to the value of the social suffering of victims. Meanwhile, the subjective theory of pain interprets it as the benefit or utility that consumers of chauvinistic ideas assign. Thus, the consumerism of male-chauvinistic values devalues the social suffering of its victims, which, nevertheless, needs to be valued. That is why patriarchal oppression is increasingly intensified, while its existence is even more invisible under a species of functional, false atheism, belonging to the male-chauvinistic feminist strategy (consisting of seizing feminist tools and perverting them in two directions: to disarm the feminist enemy - leaving them with conceptual unarmed weapons and rearming their own male-chauvinistic discourse with ideological bombs and epistemological feminist camouflage).

The fabrication of male-chauvinistic values is produced through the exploitation of victims, who invest enough time in social suffering to reproduce the consolidation of patriarchal domination. Just as a salary before exploitation means sustenance, a home before becoming a prison is a shelter.

Control, power and exploitation, in order to functionally exist, must be anchored to (preceding) basic needs, to inalienable human rights. The principle of control is difficult to understand, but easy to claim: 'you exist because I allow it'. This principle is nothing more than the formulation of a principle of existence, of theistic existence: a superior being with the ability to give and take away the existence of subordinate beings. The limits remain unseen until this principle of domain is challenged, in such a way that those exploited end up breathing below their full potential, thinking below their full potential, which leads to the oppressed accepting oppression before their own needs. It is a process commonly known as alienation, but how can this interrelation between the symbolic order of the alienating process and the material order be seen more clearly?

The objective theory of pain in patriarchal-capitalist societies explains that once woman or child are controlled and suppressed at home or in the illegality of clandestine work, the following step is to continue extending one's power through feminisation or 'virginisation' by the hand of masculine work. A process by which capital through infused copulation gets the labour force to produce the fruit of their union: the product of consumption, symbol and reality of free choice. The process is then repeated as a memorial of the first virgin birth. Thus, the symbolic and real order of prostitution has been institutionalised. The volume of the capitalist's financial investment is the quintessential symbol of excellence. And the reserve army of the unemployed is the earthly harem of the capital.

Breaking away from this unworthy situation, subject to contractual relationships, is essential. Socially subverting the capitalist material order is the key to standing tall in the symbolic order. And I say 'socially' because the patriarchal system accepts and absorbs upright individualities. For this purpose, a hollow rhetoric and paraphernalia has been developed regarding leadership, in a double sense: the museum and the zombie. Hollow museum leadership is well defined by that model of exaltation of past leaders who remain there, in the past. They fulfill a double function: to cleanse the image of the institution that condemned and/or tortured them in the past (for example, Teresa of Jesus, Joan of Arc) and to tame the original spirit of rebellion that inspired the lives of those people. And hollow zombie leadership is the neoliberal model that is promoted among the army of unemployed (unemployed: one who is not an entrepreneur). The goal is to encourage competition among those at the bottom to prevent them from looking up.

\subsection{Legitimacy level: Towards a masculinist policy}

Ceasing to breathe male-chauvinism is almost as impossible as ceasing to breath oxygen, almost like a mutation already incorporated in our psyche. Masculinism or ecomasculinism can help us in this task of ideological decontamination. Obviously, we are talking now in terms of strategic philosophy, that kind of philosophy, not descriptive, that adapts and moves the structure of modes and mechanisms of understanding reality from one field of thought to another. In short, we speak of symbolically preserving the maternal nature, the maternal forest, in which we can breathe pure air of liberation, in front of the patriarchal cement constructions that emit gases of an opium effect. 
Yet beyond the various maculinisms (trade union, childhood, equality, culture, ecology) we are now more interested in 'feminist masculinism': it studies the pain caused by male-chauvinism preferentially to women and, in general, the feminine intimacy of men and women.

It is difficult to understand, although comprehendible, the lack of orientation of feminist thought towards male-chauvinistic violence against the feminine intimacy of people, both women and men. At times, without intention, this has implied a new and unexpected source of discriminations, which generally go unnoticed as they remain hidden at an even deeper level of silence. Therefore, faced with the words of Fraser [32] regarding the 'scales of justice', it would be necessary to oppose the study of the scales of silence. Because, although praiseworthy and suggestive, the claim to justice or ethics is nothing more than a speech far from the scientific analysis of reality, just as Marx suggested. In the end, spoken ethics is nothing more than a subterfuge that in no way demands an executed ethic or active ethics. Ultimately, any claim of justice is suspended before a previous contractual agreement, be it a tacit or expressive contract. The trap is set. The only injustice that can be denounced is unchallengeable. The primordial injustice that anchors itself precedes the awareness and defence of one's inalienable needs and rights. Unchallengeable, this injustice is prescribed in the night of our times, in the primordial symbolic ordering of social relations, in the depths of silence. Lending an ear to it and correcting its effects is a basic task for emancipatory masculinist thought.

Ultimately, the social emancipation from only feminism is impossible, because we would be forgetting the masculinist thought: "For Millett, the two central principles of patriarchy are the subjection of women to men, on the one hand, and the subjection of young men to older men, on the other hand. Patriarchy operates by gender and by generation. It is also a system that is being transformed and adapted to the different economic and political systems with which it interacts, as is the case of the capitalist system. Socialisation by gender constitutes the ideological aspect of patriarchy, which goes hand in hand with those discourses that ground the difference between the sexes in biology, as occurs with Millett's judgment of Freudian discourse. And without overcoming this double mechanism of patriarchal reproduction it is impossible to establish what the differences between the sexes really are, or, in any case, whether they really exist" [33] (p. 92).

In other words, emancipation and abolition of systems of domination will not be possible without a joint sexual and generational policy. The patriarchy is not just a question of gender; it is also a generational matter. Patriarchal ideology is formed through socialisation by gender and by generation.

\section{Conclusions}

Within the frame of a masculinist way of thinking, one of the central tasks of a generational policy will be to confront the sense of guilt for being born a man, the stigma of natural violence to which all men are indiscriminately associated, without exception.

It is necessary to expand and deepen emancipatory anti-patriarchal thinking, for which we should rethink the definition of patriarchy, traditionally conceived as a sexual bodily antagonism, as if sexual self-awareness did not exist or was not natural to the body.

The patriarchy is an expression of the external subjection of the consciousness of femininity to that of masculinity, from a free conscience to an authoritarian one. In other words, it represents the yearning for submission of an authoritarian conscience over another meeker one. Freedom is thus converted into rebellion for the double legitimisation of its authoritarian violence, before itself and before other consciences. Therefore, in the face of the biologicist thesis and its sociological antithesis, we find the ideological synthesis (both natural and cultural). It is an ideological model that prioritises some values over others in order to govern social behaviour, with both biological (with direct physical or functional impacts on the body itself) and cultural effects (in a broad sense, including how to configure the economic conditions of existence).

Consequently, sexual taboos are nothing more than excuses to avoid confrontation with free sexual self-awareness, which marks the system of interpersonal pleasure between equals, because equality and diversity are not just given by the body, yet subordinately by the conscience. 
Otherwise, we would not be different from a stone or an animal, with purely mechanical and instinctive behaviour.

Sex is a toy owned by the infantilism of the dominator. Aware of its strength and its ability to impose its will, his objective is to restrict any experience of pleasure higher or rival to his own. Obviously, among those sources which rival the pleasure of control is sex, and therefore it is his priority to control it.

By definition, the pleasure of control or domination excludes the pleasure of others and has nothing to do with neither femininity nor masculinity, except in the eventual and instrumental use of strength that could occasionally be given by one of the two. The key is the infantilised awareness of the oppressor, unable to conceive projects of common interest. From feminism and masculinism, it is necessary to fight against patriarchy and against any force that limits people's capacity for self-realisation. Such forces generally adopt the form of, fundamentally, religious and economic beliefs; hence the patriarchal-capitalist monster appears, and thus springs the need for a more atheistic and feminist masculinist way of thinking.

Author Contributions: Conceptualization, Methodology, J.A.F.M.; Software, Validation, J.A.F.M. and M.P.F.; Formal Analysis, Investigation, Resources, Data Curation, Writing-Original Draft Preparation, J.A.F.M.; Writing-Review \& Editing, Visualization, Supervision, M.P.F.; Project Administration, Funding Acquisition, J.A.F.M. and M.P.F.

Funding: This research was funded by Junta de Extremadura and European Regional Development Fund, grant number [GR18095] through the DELSOS Research Group from University of Extremadura.

Acknowledgments: Thanks to José Castro and Marcelo Sánchez-Oro for their administrative support.

Conflicts of Interest: The authors declare no conflict of interest. The funders had no role in the design of the study; in the collection, analyses, or interpretation of data; in the writing of the manuscript, and in the decision to publish the results.

\section{References}

1. Caballero Wangüemert, M. ¿Hay mujeres más allá del feminismo? De la lucha por la igualdad al transhumanismo/posthumanismo. Arbor 2016, 192, (778), 1-6.

2. Lindsay, J.; Boyle, P. The conceptual penis as a social construct. Cogent Social Sciences 2017, 3, 1-7.

3. Millett, K. Politica sexual; Cátedra: Madrid, Spain, 2017, 978-84-376-3737-2.

4. Femen. Manifiesto Femen; Hoja de Lata: Gijón, Spain, 2015, 978-84-942805-9-7.

5. Boghossian, P.; Lindsay, J. The conceptual penis as a social construct: A Sokal-style hoax on gender studies. eSkeptic, 19/05/2017. Available online: www.skeptic.com/eskeptic/17-05-19/ (accessed on 21/07/2017).

6. Ngozi, C. Dear Ijeawele, or a Feminist Manifesto in fifteen suggestions. Facebook profile Chimamanda Ngozi Adichie, 12/10/2016. Available online: https://www.facebook.com/chimamandaadichie/posts/10154412708460944 (accessed on 20/06/2017).

7. Armanian, N. El derecho a la igualdad de género. XII Jornada Laicista, 29/03/2017, Murcia, Spain. Available online: https://www.youtube.com/watch?v=EZGB9mN9rPo (accessed on 19/05/2017).

8. Mollá, T. ¡Apropiémonos! Tribuna Feminista, 03/2017. Available online: www.tribunafeminista.org/2017/03/apropiemonos/ (accessed on 10/04/2017).

9. Hartmann, H. Un matrimonio mal avenido: hacia una unión más progresista entre marxismo y feminismo. Zona Abierta 1980, 24, 85-113.

10. Delphy, C. Por un feminismo materialista: El enemigo principal y otros textos; La Sal: Barcelona, Spain, 1982, 978-84-85627-17-2.

11. Azurra, C. Las sin parte. Matrimonios y divorcios entre feminismo y marxismo; Izquierda Anticapitalista: Madrid, Spain, 2010, 978-84-942-9813-4.

12. Pérez Orozco, A. Subversión feminista de la economía; Traficantes de Sueños: Madrid, Spain, 2014, 978-84-96453-48-7.

13. Jennings, A. Public or private? Institutional Economics and Feminism. In Beyond Economic Man: Feminist Theory and Economics; Ferber, M., Nelson, J., Eds.; University of Chicago Press: Chicago, USA, 1993, pp. 111-130, 978-02-262-4208-8. 
14. Mayhew, A. Institutional Economics. In The Elgar Companion to Feminist Economics; Peterson, J., Lewis, M., Eds.; Edward Elgar: Cheltenham, UK, 1999, pp. 479-485, 1-85898-453-X.

15. Danby, C. Toward a Gendered Post Keynesianism: Subjectivity and Time in a Nonmodernist Framework. Feminist Economics 2004, 10, (3), 55-76, 10.1080/1354570042000267626.

16. Austen, S., Jefferson, T. Feminist and post-Keynesian economics: challenges and opportunities. Cambridge Journal of Economics 2010, 34, (6), 1109-1122, 10.1093/cje/bem046.

17. Gudynas, E. Debates sobre el desarrollo y sus alternativas en América Latina: Una breve guía heterodoxa. In Más allá del desarrollo; Lang, M., Ed.; AbyaYala: Quito, Ecuador, 2011, pp. 21-54, 978-99-420-9053-9.

18. Gálvez, L. Una lectura feminista del austericidio. Revista de Economía Crítica 2013, 15, (1), 80-110.

19. Quiroga, N. Economía feminista y decolonialidad, aportes para la otra economía. Voces en el Fénix 2014, 37, 36-45.

20. Vega, S. Sumakkawsay, feminismos y post-crecimiento: articulaciones para imaginar nuevas utopías. In Post-crecimiento y buen vivir. Propuestas globales para la construcción de sociedades equitativas y sustentables; Endara, G., Coord.; Friedrich Ebert Stiftung, Ecuador FES-ILDIS: Quito, Ecuador, 2014, pp. 353-372.

21. Carrasco, C. La economía del cuidado: planteamiento actual y desafíos pendientes. Revista de Economía Crítica 2011, 11, 205-225.

22. Herrero, Y., Cembranos, F., Pascual, M., Coord. Cambiar las gafas para mirar el mundo: Una nueva cultura de la sostenibilidad. Libros en Acción: Madrid, Spain, 2011, 978-84-93678-55-5.

23. Pérez-Prieto, L., Domínguez, M. Una revisión feminista del Decrecimiento y el Buen Vivir. Contribuciones para la sostenibilidad de la vida humana y no humana. Revista de Economía Crítica 2015, 19, 34-57.

24. Picchio, A. Social Reproduction: the Political Economy of the Labour Market. Cambridge University Press: Cambridge, UK, 1992, 0-521-41872-0.

25. Jubeto, Y., Larrañaga, M. Aportes del institucionalismo radical al impulso de la equidad de género en procesos de transformación social. In La cooperación y el desarrollo humano local; Larrañaga, M., Coord; Hegoa: Bilbao, Spain, 2011, pp. 39-58.

26. Federici, S. Revolución en punto cero. Traficantes de Sueños: Madrid, Spain, 2013, 978-84-96453-78-4.

27. Pazos, M. Desiguales por ley. Los Libros de la Catarata: Madrid, Spain, 2013, 978-84-83199-94-7.

28. Carrasco, C., Ed. Con voz propia. La Oveja Roja: Madrid, Spain, 2014.

29. Agenjo, A., Molero, R., Bullejos, A., Martínez, C., Coords. Hacia una economía más justa. Manual de corrientes económicas heterodoxas. Economistas sin Fronteras: Madrid, Spain, 2017.

30. Cendrowsky, H., Martin, J.P., Petro, L.W. The Handbook of Fraud Deterrence. John Wiley \& Sons: Hoboken, New Jersey, 2007, 978-0-471-93134-8.

31. Giannakas, K., Kaplan, J.D. Policy design and conservation compliance on highly erodible lands. Land Economics 2005, 81, (1), 20-33, 10.3368/le.81.1.20.

32. Fraser, N. Escalas de justicia. Herder Editorial: Barcelona, Spain, 2008, 978-84-254-3028-2.

33. Posada, L. Sexo, vindicación y pensamiento. Huerga y Fierro: Madrid, Spain, 2012, 978-84-837-4854-1. 